Etikonomi

Volume 16 (2), Oktober 2017

P-ISSN: 1412-8969; E-ISSN: 2461-0771

Page $231-248$

\title{
Starbucks's Fair Trade in The Edge of Globalization
}

\author{
Saomi Rizqiyanto \\ Universitas Muhammadiyah Jakarta \\ saumiere@gmail.com
}

\begin{abstract}
Starbucks as a global company that reflect American values plays an important role in the trade of coffee industry. In February 2000, Starbuckes partially adopted the Fair Trade and in early 2001 Starbucks fully adopt Fair Trade. This research seeks to examine the relationship between Starbucks as a symbol of globalization with Starbucks as a global corporation who adopt Fair Trade. This study also seeks to explain how any practical Starbucks Fair Trade as a whole and uncover the reasons behind Starbucks adopt Fair Trade. The research uses a case study method and using a primary and secondary reference sources in the form of books and journals. As a results, this study indicate that Starbucks has strong reasons that ultimately makes the company adopted the Fair Trade. The adoption of Fair Trade also known as CAFE Practices is apparently not spared from criticism of the observer of Fair Trade.
\end{abstract}

Keywords: starbucks, globalization, fair trade, CAFÉ's Practices.

\begin{abstract}
Abstrak
Starbucks sebagai korporasi global yang mencerminkan nilai-nilai Amerika berperan penting dalam perdagangan industri kopi. Mulai Februari 2000 Starbucks secara resmi mengadopsi Fair Trade dan pada awal 2001 secara sepenubnya Starbucks mengadopsi Fair Trade. Penelitian ini berupaya untuke mengkaji kembali bubungan antara Starbucks sebagai lambang globalisasi dengan Starbucks sebagai korporasi global yang mengadopsi Fair Trade. Penulisan ini juga berupaya menjelaskan bagaimana praktik Fair Trade Starbuck secara keseluruban dan mengungkap alasan-alasan dibalik Starbucks mengadopsi Fair Trade. Penelitian ini menggunakan metode studi kasus dengan menggunakan sumber sumber referensi primer dan sekunder baik berupa buku maupun jurnal. Hasil dari penelitian ini menunjukkan bahwa Starbucks memiliki alasan-alasan kuat yang pada akbirnya membuat perusabaan ini mengadopsi Fair Trade. Proses adopsi Fair Trade yang dikenal dengan istilah CAFE Practices ini ternyata tidak luput dari kritik para pemerhati Fair Trade.
\end{abstract}

Kata Kunci : starbucks; globalisasi, perdagangan adil, praktik CAFE

Received: April 5, 2017; Revised: June 16, 2017; Approved: July 7, 2017 
Starbuck's Fair Trade in The Edge

Saomi Riziyanto

\section{INTRODUCTION}

One of the most frequently traded products in the world besides oil is coffee. The data shows sales of coffee beans throughout 2013 were more than 144 million coffee sacks which equivalent to 7 billion kilograms of coffee beans that exported successfully by 57 coffee exporting countries. From the list of exporting countries, the biggest three exporting countries are Brazil followed by Vietnam. Indonesia itself is in third place with total exports reaching more than 12 million of coffee sacks valued at 637 million kilograms of coffee beans (International Coffee Organization, 2014).

Unlike the sale of coffee beans, coffee sales in the form of paper cups data show that exceed expectations. In the United States, the National Coffee Association launches a surprising new find. Almost 83\% of American adults consume coffee, up five percent from last year, which reached $78 \%$. That number if compared with coffee paper cup reached more than 587 million cups. On average most American adults aged 21-40 years drink 2 to 3 cups of coffee a day. This data shows that the United States is the largest consumer for coffee sales (National Coffee Association, 2014). Nevertheless, individual US coffee drinking habits are defeated by Finland which reaches $9.6 \mathrm{~kg}$ per capita per year, while the United States alone is only $3.1 \mathrm{~kg}$ per capita per year. (International Coffee Organization, 2014)

The high demand for coffee both in the form of coffee beans and cups encourages large industries to plunge in this field. One of them is Starbucks. This producer is one of the strong companies in the coffee business since starting in the decade of 90 's until present. Starbucks was originally a single coffee shop in Seattle in 1970, and then turned into a global American corporation. Recent data shows if Starbucks already has more than 21 thousand coffee shops worldwide, employing more than 180 thousand employees in 55 countries with a capitalization value of up to 55 billion US Dollars. (Forbes , 2014)

There are several reasons that make Starbucks king in this industry, first is of course the products that Starbucks sells are different from other coffee giants, such as Nestle. Starbucks began introducing the culture of drinking coffee outdoors and taking advantage of the rush hour at the center of the working community (Harford, 2006). Secondly, it is a remarkable advertising campaign, from movies, music, posters, to their relationships with world celebrities. (Harford, 2006)

In addition there are other things that encourage people to then consume coffee at Starbucks coffee shop. The Starbucks campaign on the Fair Trade scheme, which 
propagates fair trade between coffee farmers and producers is enough to make people aware of the fair trade scheme and ultimately choose Starbucks as a coffee shop, in addition to stylish, this shop also offers other value added that is social awareness for farmers.

Fair Trade is an initiative initiated by the International Fair Trade organization that aims to offer a more profitable sale and purchase scheme for both parties. The main purpose of the Fair Trade movement is to provide an appropriate price to small-scale coffee farmers in developing countries to improve their lives. Starbucks adopted the Fair Trade scheme in 2000 through a scheme called the CAFÉ Practices (Coffee and Farmers Equalities) that have Fair Trade-like standards and principles.

The Fair Trade Starbucks campaign needs to be questioned again given the research done by many people found a mistake in Fair Trade Starbucks practice. As stated by The Organics Certified Association found that many consumers are deceived by the Fair Trade Starbucks campaign, since only 6 percent of all coffee coming from the Fair Trade trade schemes is the self-made Fair Trade scheme (Paul \& Cummins, 2014).

The Christian Science Monitor page launched a similar report entitled "Follow your label; Starbucks coffee farmers who never heard of Starbucks ". This coverage follows the Fair Trade Starbucks implementation pattern in Central America precisely in Colombia. The result is quite surprising, farmers in Colombia had been promised to get Starbucks assistance but they were never introduced to the Fair Trade Starbucks scheme (Timmerman, Follow Your Labels: Starbucks Coffee Farmers Who Never Heard of Starbucks, 2013) .

Based on the findings that the researchers found above, in this study, the author tries to express more in the relationship between Starbucks as a symbol of globalization with Starbucks as a global corporation that applies the principles of Fair Trade. In this study the authors formulate two problems as follows, first how the relationship between Starbucks as a global company symbol of America with the Fair Trade movement. Secondly, why did Starbucks adopt Fair Trade following criticism from this adoption? By using literature study method, the author tries to parse the problem.

\section{METHOD}

This type of research is included in the case study that is the type of research with a qualitative approach where researchers review a system as a whole or at some system in 
Starbuck's Fair Trade in The Edge

Saomi Riziyanto

some time in detail based on in-depth data collection from various sources. Sources of sources in question is the observation, interviews, tracking documents and reports. (Creswell, 2007) While the type of case study approach the author uses is the intrinsic type. The intrinsic case study is used if the intentions of the researcher are to gain a better understanding. (Baxter \& Jack, 2008)

The research method used in this research is literature study. Library study is any attempt made by researchers to collect information relevant to the topic or problem to be or is being researched. The type of data used in this study is qualitative sourced from the primary data and secondary data obtained by conducting literature study is data collection by studying written materials such as books, literature and other writing materials.

\section{RESULT AND DISCUSSION}

\section{Phenomena and Characteristics of Globalization}

Globalization is a phenomenon, the only system inevitable by humans. One opinion that says globalization is the inevitable system is Stuart Eizenstat. In 1999 Stuart Eizenstat, deputy minister of state for business and agricultural economics at the time of Bill Clinton expressed the opinion that "Globalization is an inevitable element in our lives. We cannot stop it any more then we can stop the waves from crashing on the shore." (Eizinstat, 1999). In line with Eizenstat, Samuel Berger, Security Advisor in the same era with Eizenstat said globalization is not an option but a single and a growing fact (Skonieczny, 2010).

The main characteristic of globalization is the value of America. There is one indisputable fact that we live in this era of globalization, namely the interdependence and the power of a single superpower named America (Friedman, 2000). W.T Stead in his book The Americanization of The World tries to explain why globalization is also Americanization. He described clearly a British man who woke up with a bedcover made in Istanbul, using an electric haircut from China while his wife was cooking bacon from Mexico. Elsewhere in the UK, in the Middle East, scientists in the area teach some principles of the declaration of American independence. Stead's depiction really confirmed the Americanization that was engulfing the early 20th century. (Iriye, 2007)

The Americanized-colored Globalization discourse has several traits. In addition to his tendency to promote Peace, Prosperity and Justice, there are other characters described by Iriye (2007). First, American commodities, Obviously this character is a major marker where US manufactured goods are flooding the markets in many countries. Second, 
Number of NGOs and multinational companies. Multinational Company is able to build relationships of goods, and labor, between continents and oceans, from America to Japan, from America to the UK and so on. While NGOs disseminate ideas of tolerance, the environment, cultural exchanges, education and so on. The third character is the emergence of America's global or multilateral institutions. Many world institutions were formed during the post-war world two, such as: IBRD (world bank), United Nations, GATT, IMF and others (Iriye, 2007).

\section{The Irony of Globalization, Inequality of Income}

Globalization becomes a phenomenon because of the impact it produces. This system gave birth to two blades. Globalization brought mankind on unprecedented wealth and unprecedented poverty. (Stiglitz, 2002) These two things are what make globalization into a phenomenon and scientific study that will never run out for research.

Stiglitz often noted the irony of globalization and presented to the reader, the author of two things alluded to above, and the well being of countless untold poverty. Globalization is synonymous with free international trade allows many countries to boost the growth of the export sector. In the export-driven growth, the rich countries shift labor base to countries with cheaper labor force, such as Bangladesh. This flow brings many benefits, many young men who labor, and have a better income than breeding or living on the farm. For many pro-globalization countries, this flow, we are familiar with the term outsourcing, is progress. But that is often forgotten by many people was recorded, while the developed countries enjoyed growth of 2.5 percent per year, the countries where outsourcing, precisely the people who wallow in poverty increased by 100 million (Stiglitz, 2002)

In addition to the above paradox, Stiglitz also often reminds pro-policy makers of globalization that this system also creates an endless and repeated crisis. Since the Great Depression that hit the United States in 1929, the crisis unceasingly overshadowed the global economy. Starting from the Latin American financial crisis in 1980, then the Asian Crisis in 1998, Great Recession in 2008, and the European Crisis in 2012 until now. Finally, the United States was shocked to learn that the country that has not recovered from the subprime mortgage crisis would be faced with a student loan crisis.

For the author, the two things, inequality and crisis are the irony of globalization itself. The effects of globalization are not as beautiful as what is described in the theories of globalization in the classroom. Syamsul Hadi has the right picture in his opinion on 
Starbuck's Fair Trade in The Edge

Saomi Riziyanto

Kompas 7 June 2010. He mentioned that globalization is like a blank check, which initially generates hope but can not be cashed.

Fair Trade is one of the efforts to overcome income inequality. This system is a sustainable alternative movement in relation to the exchange of goods and production to anticipate free market mechanisms or globalization. Many argue that Fair Trade is a consumer movement such as Boycott or Anti Animal Testing. But along with the complexity of this movement and the many scholars who research on Fair Trade, Fair Trade is no longer just a movement. The system is also an overarching mechanism with many institutions involved. In addition, this system also has a broad impact for the economy of society (Hudson and Hudson, 2004).

This study uses the term Fair Trade which is interpreted as fair trade. In Fair Trade terms means trade partnerships based on dialogue, transparency, and respect aimed at seeking greater commonality in international trade. Fair Trade contributes to sustainable development by offering better trade conditions, securing the rights of marginalized producers, especially in the South. Fair Trade can define as a labeling initiative aimed at improving the lives of poor people in developing countries by offering better terms and conditions to producers and helping producers to organize themselves. (Dragusanu, et.al, 2014)

The definition of Fair Trade so far does have a diversity of definitions because there is no single authority governing this system. Countries in Europe agree on a single permanent and temporary definition in the United States, there are some organizations that follow the European provisions but there is also a Fair Trade organization that uses its own definition. But whatever it is there is one way to identify and define the definition of Fair Trade is a system that offers better trade terms to producers in developing countries.

Fair Trade trading system has several goals but the most important and most important is to provide the appropriate price to meet the basic necessities of life for the producers. As we know, the initiative of this trading system is to develop a viable life for producers. Redfern and Snedker (2002) put forward six goals of the Fair Trade movement itself: (1) To improve the livelihood and prosperity of producers by increasing market access, strengthening producer organizations, paying better prices and providing continuity in trade relations; (2) To promote development opportunities for disadvantaged producers, especially women and indigenous peoples, and to protect children from exploitation in the production process; (3) To raise awareness among consumers of the negative impacts of 
international trade on producers so that they channel their purchasing power positively; (4) To model examples of partnerships in trade through dialogue, transparency and respect; (5) To campaign for changes to rules and practices on conventional international trade; (6) To protect human rights by promoting social justice, voicing environmental protection and economic prosperity.

Fair Trade is not a new system. The embryo of this system has existed since the era of colonialism. Nevertheless, many experts who disagree with the initial opinions of the Fair Trade movement emerged. The Fair Trade Resource Network notes that the appearance of Fair Trade began when Edna Ruth Byler, a US citizen imported handicrafts from women women in the interior of Puerto Rico in 1946 due to Europe's troubled supply due to World War II. Dragusanu, et.al (2014) wrote that the emergence of the modern Fair Trade accompanied by labeling occurred in 1988 when the spiritual organization in the Netherlands initiated the Max Havelaar labeling movement. Max Havelaar's movement was inspired by Multatuli's fictional essay that defended the fundamental rights of coffee farmers in Java. These peasants suffer from forced cultivation systems, they work with poor working conditions, long working hours and inadequate wages.

Inspired by the novel, this faith-based organization called itself Max Havelaar and also practiced the same thing. Aim to ensure that farmers in developing countries earn decent wages. Only a decade later, replica of this organization began to appear in many European countries and even up to North America. Until 1997 came two major organizations, Fair Trade in Europe and Trans Fair in the United States. These two organizations take shelter under an umbrella organization called Fair Trade International. (Dragusanu, et.al, 2014)

In 2012, the United States-based Trans Fair split from Fair Trade International and tries to create its own certification This is triggered by the mismatch in choosing suppliers / producers. Fairtrade International believes that the fairtrade label is only for smallholders and producers while USA transfers think if big players are allowed as long as they have a transparent source. (Dragusanu, et.al, 2014). Up to now, there are more than 250 organizations such as TransFair / FairTradeUSA campaigning on fairtrade and promoting it all over the world. These organizations are both trying to promote the main objective of the fairtrade itself, which is to find a worthy appreciation for the farmers. 
Starbuck's Fair Trade in The Edge

Saomi Riziyanto

This study argues that Fair Trade is a movement or scheme that emerges as a response from Globalization. Fair Trade is a consumer movement that is resistant to globalization, whether consciously or unconsciously. Fair trade categorize it as a consumer power to respond to globalization through a labeling system that breaks in and destroys the corporate system (Anderson, et.al, 2005).

Fair Trade is a form of social movement through an entrepreneurial partnership that tries to take a different approach in addressing poverty. Unlike globalization, which creates inequality, Fair Trade enters and changes the trading system from within, through the power of consumers and offers better conditions. (Hiscox, 2007)

Most consumers who buy Fair Trade products are people who are aware of issues of globalization, income inequality, poverty in third countries and are ethically moved to change that condition with buying power. This statement in Theory of Reasoned Action and Theory of Planned Behavior contains two things, namely perception, how consumers view sensitive issues and attitude how consumers take action as a form of attitude statement. (Bondy and Talwar, 2011)

The power of consumers turns out to be the most important driver of the current Fair Trade development. Recorded in 2007, sales data of products with Fair Trade certification reached 2.4 Billion US Dollar rose to $47 \%$. This phenomenon is considered a shift of Fair Trade from an alternative system to a mainstream, although the market share of Fair Trade certification products reaches only 1\% of the total traded products. (Bondy and Talwar, 2011)

Many researches that conducted both in Western Europe and in North America show similar results. The survey, conducted in Britain by Kimberley Elliot and Richard Freeman, for example, states that 74 percent of people will buy products with labels that care about social and environmental issues. 42 per cent of Swiss citizens claim to be aware of and understand the products of Fair Trade labeled products, while in the United States alone, a survey conducted by the same researcher suggests that 12 per cent of Americans are aware of Fair Trade labels and understand the purpose of the label. Although it can be concluded also that consumer awareness of Fair Trade is higher in Europe than in America. (Bondy and Talwar, 2011)

This study argues, Starbucks is a mirror of America that reflects the values; standards and tastes typical of America are introduced throughout the world through a medium cup of coffee. Since its founding in 1971 at Pike Place Market, Seattle, United 
States, Starbucks has continually established itself as an American icon. Starting from a coffee bean shop, Starbucks went on to become the number one coffee producer, ran a retail coffee shop in the busiest corners, once a producer of films, music and bookstores, before finally returning to the coffee core business. Then it evolved into a Hollywood lifestyle icon and shortly, began to pair with McDonalds, GM, Coca Cola and MTV as styles that reflect the global American culture.

Perhaps the adagium is true, because exactly one year before America entered a major recession in 2008, Starbucks has actually been 'feverish', the company led by Howard Schultz this throughout 2006 to 2009 has closed hundreds of coffee shops in America and lay off thousands of employees, After fifteen years of unending growth. What happened to Starbucks also happened to America in those years. It is no exaggeration to conclude that Starbucks has now become a new style of US capitalism.

Starbucks is a pioneer in rolling out national and international issues and making it a plus for the company. Earlier this year alone, in a Starbucks forum where Starbucks executives gathered, the CEO mentioned that Starbucks would be a free place where racial discussions are not limited. In addition to race issues, by 2013 Starbucks also initiates full tuition for starbuck employees both fixed and part time, to pursue their undergraduate degrees both in college and university. In order to honor the services of war heroes, Starbucks initiated work for veterans. In addition Starbucks also recorded through The Schulz Family Foundation provides free training for people with disabilities who work in the retail industry and small medium enterprise. (Foroohar, 2015)

The warmest and most likely caucus of debate is when Starbucks declares its commitment to the source of ethically obtained coffee beans, through the Fair Trade scheme. An ethically obtained seed source campaign through the Fair Trade scheme is the hot issue when Starbucks is climbing into a global company. In August 1999, Ben Packard, one of the Starbucks officials in the Global Responsibility section, met with Paul Rice, executive officers from TransFair USA. Ben studied the purchase scheme of Fair Trade coffee in TransFair USA. A month later, Paul was invited to Starbucks headquarters in Seattle and talked to Starbucks executives, including the CEO of Orin Smith. Paul explained that the Fair Trade TransFair USA scheme provides tremendous benefits, in addition to protecting farmers and benefiting businesses, as it gets the right product. Through certification and Fair Trade TransFair standards will add Starbucks credibility value. The explanation of TransFair USA on Fair Trade does not necessarily adopt 
Starbuck's Fair Trade in The Edge

Saomi Riziyanto

Starbucks Fair Trade. Paul Rice acknowledges that it may take a long time for Starbucks to implement Fair Trade in the process of purchasing its coffee beans (Stanley, 2002).

The Starbucks decision to adopt Fair Trade took place in February 2000 when Orin Smith called all Starbucks executives to decide on this issue. After listening to some opinions from his subordinates, Orin decided that Starbucks would buy coffee under the Fair Trade scheme. (Stanley, 2002)

When Starbucks adopted Fair Trade in 2000, Starbucks undertook a series of massive marketing via television, newspapers, radio and the Internet on the image of Starbucks as a company whose source was ethically obtained. As a result Starbucks sales rose 9\% (Reynolds, starbucks sales boosted fairtrade espresso shot, 2014). From here it can be concluded beyond the controversy of the campaign and its history, Starbucks successfully negates itself as an ethical company, concerned about the fate of coffee farmers. This study focuses on the reasons why Starbucks is finally adopting Fair Trade and the effects of this adoption.

One of the big reasons that encouraged Starbucks to adopt the Fair Trade system according to the author's opinion is that there is a huge boost from demonstrators who demand Starbucks to apply the Fair Trade principle. It is the Global Exchange, one of the nonprofit organizations that initiated demonstrations demanding Starbucks to pay attention to the fate of coffee farmers in third countries. In addition to these demands, Global Exchange even threatened to campaign boycott nationally. Orin Smith understands that these demands and threats can happen and target all companies, but the CEO knows that his company will face serious problems if they do not respond. (Stanley, 2002).

Global Exchange is a non-governmental organization founded in 1988 at San Fancisco. The company has a mission of raising public awareness in the United States and the world about the role of global corporations in human life. The role that is often targeted by Global Exchange is that corporations often seek the most inexpensive resources to increase profit margins, which in practice also often ignore local workplace and environmental conditions.

Global Exchange at the end of the millennium precisely in 1999 successfully targets Starbucks. At that time the anti-globalization sentiment was strengthening and the peak was in 1999 at a summit of WTO member ministers in Seattle, the headquarters of Starbucks. At that time thousands of demonstrators took to the streets to blockade and protest the WTO trial at the Convention Center that in addition to the WTO global 
corporate executives also attended ministers. The New York Times illustrates that on November 29, 1999 the National Guard dropped a local police force to discipline the demonstration known as the Battle of Seattle, deemed to have undermined public order for using molamic bam. (Verhovek \& Greenhouse, 1999).

Global Exchange took advantage of this situation by aiming at Starbucks, which at that time almost closed down all its stores in Seattle including headquarters. According to Deborah James, chairman of Global Exchange, by targeting the company, the awareness of the community can quickly emerge. James explains by aiming at Starbucks, then his mission will be delivered, Starbucks according to James, "its the company people love to hate" (Stanley, 2002). James and all Global Exchange demonstrators at the time demanded Starbucks to use coffee beans from the Fair Trade scheme and threatened that they would promote Starbucks boycott if not met. (Stanley, 2002).

The demand factor in the author's perspective is the second reason behind the Starbucks decision to adopt Fair Trade in early 2000. Alison Stanley's finding revealed that before Starbucks decided on Fair Trade adoption, there were two-consumer research results that led to the decision. The first research came from Cone Communication explaining that 62 percent of respondents will replace brands or products that support the issues they are looking at. For example, women replace their beauty products that do not use animals as a test tries. Starbucks thinks that by bringing Fair Trade in addition to increasing customer loyalty will also explore new consumer demographics. (Stanley, 2002)

The second research came from Alison Maitland that was launched in 2001. The results of the study prove that 75 to 80 percent of consumers will reward a company that applies the principles of ethical principles; the remaining 20 percent will leave companies that do not care about social issues. Starbucks as a consumer-care company sees this as another reason for its decision to adopt Fair Trade. (Maitland, 2002)

The third survey that is a strong reason for Starbucks to adopt Fair Trade is that Starbucks understands the Luxury Intitute report that many Americans, wealthy and well educated want a company that behaves ethically carries out its responsibility for social issues. Starbucks once again succeeded with hope of hope (Simon, 2009).

Starbucks uses this second reason as a 'sensible choice' because Starbucks wants to impress all consumers and stakeholders that customers always come first. By looking at consumer-based research needs, Starbucks wants to minimize the impression that 
Starbuck's Fair Trade in The Edge

Saomi Riziyanto

Starbucks adoption decisions are due to demonstrators' demands, but because they see consumer needs.

The existence of market opportunities for Fair Trade quality products with premium prices in the author's opinion is another reason behind the Starbuks decision to adopt the Fair Trade system. Although conspicuous consumption theory can be applied where and for any product, Starbucks provides a different pricing policy for Fair Trade products. In the Starbucks store page, it is clear that products with Fair Trade International and CAFÉ Practices Conservation International certifications are priced higher than coffee of the same type. This indicates that there is a market opportunity to create its own niche for Fair Trade products.

This opportunity fits perfectly with the conditions of the United States where it was enjoying the economic boom in the 1990s. America in the early 90s was becoming a rich country and a very productive society. Between 1980 and 1999 there was a significant increase in the annual income of American society, from 15,744 US Dollars to 21,239 US Dollars. According to the US Treasury report, annual income of Americans has increased by 35 percent in just two decades (Clark, 2007).

At this point the authors believe there is a meeting point between market opportunities and the conditions of American society unions that are in the economic boom. The American community had what it called the Post Need Worlds. It describe the situation where middle-class citizens in America get everything they need, home, food, education; they want something more than necessary (Schor, 1999).

Like a knife, a system that is born always creates a positive side and a negative side. Can cause pros and cons, and also criticism for a system. Globalization for example has given birth to prosperity but it also gave birth to the gap. As well as Starbucks as a symbol of globalization, when adopting the Fair Trade system, it has the benefit of giving rise to impact and criticism.

Starbucks in adopting Fair Trade has obviously spawned criticism from various Fair Trade observers. From Kelsey Timmerman who criticized Starbucks for not entirely practicing Fair Trade to Maria Christine Renard who sharply criticized the application of CAFE Practices that paid no attention to small farmers and marginalized peasant unions. Below are four complete criticisms that the author is trying to present in this thesis.

The application of Fair Trade Starbucks in the end according to the author's opinion is not like the claims made by Starbucks, that $86 \%$ of their coffee is sourced from 
CAFÉ Practices. How not, Fair Trade, in principle, is to apply direct trade between producers and large corporations, which at least make Starbucks relationships with farmers closer, somehow not so experienced. Colombian farmers who are already CAFÉ Practices Starbucks partners have never heard of Starbucks. (Timmerman, Starbucks coffee farmers who never heard of Starbucks, 2013)

Timmerman released his research results on the Christian Science Monitor page. He follows the origins of coffee with a fairtrade label, and he targets Starbucks. Is it true that Starbucks applies the fairtrade principle as well as the packaging label? Because as we know, 8\% Starbucks coffee is Fairtrade certified, most Starbucks get the certificate label from Transfair USA, a fraction of Fairtrade International. The remaining $86 \%$ of Starbucks coffee beans come from its own Starbucks partnership program, CAFÉ Practices which is an adoption of Starbucks values (Timmerman, Starbucks coffee farmers who never heard of Starbucks, 2013).

Kelsey's quest gets rejected in search of data from inside sources. It has become a standard public relations Starbucks to say that Starbucks does not disclose information for the writing of books, theses and the like, "The information that you are requested is private and confidential". Through her own efforts, Kelsey finally went to Colombia, where the Andes are like a coffee-bean blanket, as far as the eye sees most of it as a coffee plantation. Using ethnographic research methods, where Kelsey disguised himself and became a peasant worker, Kelsey asked many coffee farmers in El Tabo De Gomez, a village near the Andez mountains of Colombia where most of the population were workers or owned coffee farms.

The result is found very paradox information. First, Starbucks in a report published under the CAFÉ Practices program in Colombia claims that $86 \%$ of the coffee they obtained came from Colombia theoretically, for adopting the Fair Trade principle, purchasing the price of coffee beans in a premium, able to prosper the lives of coffee farmers. Second, but the claim was not in line with the findings on the ground, even the five farmers Kelsey asked about the sacks of the CAFÉ practices logo did not understand and never even heard what Starbucks.

If Kelsey Timmerman points out that farmers in Colombia never know what Fair Trade Starbucks is, unlike Renard (2010) find that Fair Trade is able to uplift the condition of the farming community in Mexico but the implementation of CAFÉ Practices makes it a blurry line, whether CAFÉ Practices is helping or complicating it. Farmers and coffee 
producers in Mexico before getting to know the Fair Trade System especially the Starbucks CAFÉ Practice Program are in a disempowerment position, where the coffee supplies chain from coffee farmers to coffee producers uses conventional systems. Whereas coffee production plays an important role in the Mexican economy, accounting for about 30\% of total exports. However, the high economic value of coffee does not affect the economic condition of the community where farmers and producers live in a 'high level of poverty' (Renard, 2010).

The situation of farmers and smallholder improved when the transformation of the distribution channel in the form of Fair Trade system. Fair Trade itself is a 'short circuit' of farmers to large producers, at which time an organization called Alternative Trading Organization initiated it. ATO NGOs initiate a shorter supply chain, this institution specifically collects small farmers and buys their coffee beans for sale to the international market. Cutting this system at least makes the powerlessness of the small farmers to be reduced. Farmers and coffee producers in Mexico before getting to know the Fair Trade System especially the Starbucks CAFÉ Practice Program are in a disempowerment position, where the coffees supply chain from coffee farmers to coffee producers uses conventional systems. Whereas coffee production plays an important role in the Mexican economy, accounting for about $30 \%$ of total exports. However, the high economic value of coffee does not affect the economic condition of the community where farmers and producers live in a 'high level of poverty' (Renard, 2010)

Unlike ATO institutions, Starbucks is another form of corporate institution that directly buys coffee from farmers through the CAFÉ (Coffee and Farmer Equity) program. CAFÉ Program Practice introduced in 2001 "demands that suppliers meet minimum requirements for both quality and 'economic accountability'. This requires full traceability of coffee from individual producer to Starbucks, and also what Starbucks considers to be acceptable levels of equity in the distributions of profit across the supply chain. "

In addition, the CAFÉ program also requires participants to pay attention to social and environmental sustainability around coffee production. Participation CAFÉ does not specialize in small farmers, all players are allowed to participate but only meet the CAFÉ Program Practice standard. In this application, Starbucks CAFÉ Practices does not play no role as a short circuit, Starbucks allows anyone to play in this distribution channel provided that transparency of distribution flow and transparency of fair payments to farmers. (Renard, 2010). 
One of the main principles of Fair Trade, which is also adopted in the CAFÉ Practices of Starbucks certification system, is to increase coffee farmers' income through economic accountability principles. In practice, however, Starbucks CAFÉ Practices often ignores the fact that farmers who are partners are not getting the promised welfare. Starbucks CAFÉ Practices often evaluates the produce, then assesses whether it complies with the CAFÉ Practices standard, otherwise Starbucks advises but still buys coffee beans without a premium price.

This opinion the author pointed out after reading the findings from Dan Charles in the US National Public Radio website. According to Charles, there is a common thread between all existing certification systems, such as Rainforest Alliance, Fairtrade International, Organic Certification and so on, namely the protection of the environment while securing the conditions of the workers. Nevertheless, each certification has a major emphasis. Fair Trade for example, one of its principles is to protect the environment, but the main purpose is to provide a premium price to farmers.

Charles gave the whole story of how the Fair Trade prevailed in Costa Rica in his report entitled "Coffee for A Cause: What Do Those Feels Good Labels Deliver?" According to Charles, Fair Trade runs in Costa Rica so far are in line with what is expected, As experienced by Louis Fernando Vazquez. Louis, who owns a coffee plantation in Central Valley, San Roman, Costa Rica, is told that in recent years, the method of planting coffee on his estate and his friends' estates has undergone significant changes. In the past, he and his friends always cleared the parasite that grows around his coffee plant, but now he let the parasite grow because according to the consultant, the parasite gives a good taste to coffee and avoids the soil from soil erosion. (Charles, 2013)

But this practice went awry when a major coffee trade star, Starbuks, through Fair Trade USA, demanded that coffee beans sold in accordance with the standards of coffee beans sold in his shop. In addition, FairTrade USA also wants major supplier suppliers to participate in this mechanism. In fact, the Fair Trade principle is only the desire of small farmers and cooperatives that can play in Fair Trade mechanism. Two of these reasons which according to Christian Mora is the main cause why Fair Trade USA which was formerly named Trans Fair USA split from Fairtrade International. 
Starbuck's Fair Trade in The Edge

Saomi Riziyanto

\section{CONCLUSION}

Fair Trade system is a real effort that emerged as an anticipation of the phenomenon of globalization. Fair Trade provides a direct solution to the poverty and inequality of income born from globalization. Fair Trade provides the basic price as well as additional prices for each farmer and small entrepreneur so that they can live well and be able to pay attention to the condition of the surrounding environment. The noble purpose of applying a system often gets a moral hazard challenge precisely from an inner player who has different motives. The application of Fair Trade Starbucks is a form of moral hazard to the Fair Trade system. Starbucks always argues that Fair Trade does not guarantee that Fair Trade's product supply complies with the standards of its company. The argument becomes a shield for Starbucks to get another supply and even by creating its own Fair Trade standard called CAFÉ Practices.

\section{REFERENCES}

Anderson, S., Cavanagh, J., \& Lee, T. (2005). Field Guide To The Global Economy. New York: The New Press.

Bondy, T., \& Talwar, V. (2011). Through Thick and Thin; How Fair Trade Consumer Have Reacted to The Global Economics Recession. Journal of Business Ethic. 101(3): 365-383.

Charles, D. (2013). Coffee For A Cause: What Do Those Feel-Good Labels Deliver? Retrieved from US National Public Radio: http://www.npr.org/sections/thesalt /2013/04/24/177757797/coffee-for-a-cause-what-do-those-feel-good-labels-delive r. Accessed on September 20, 2016.

Clark, T. (2007). Starbucked, A Double Tall Tale of Caffeine, Commerce and Culture. New York: Hachette Books.

Dragusanu, R., Giovannuci, D., \& Nun, N. (2014). The Economics of Fair Trade. Journal of Economics Prespective. 28 (3): 217-236.

Friedman, T. L. (2000). Understanding Globalization: The Lexus and The Olive Tree. New York: Picador USA.

Harford, T. (2006). The Undercover Economist: Exposing Whay The Rich are Rich, the Poor are Poor-and Why You Can Never Buy A Decent Used Car. Oxford: Oxford University Press. 
Hiscox, M. J. (2007). Fair Trade and Globalization. Cambridge: Department of Government Harvard University.

Hudson, M., \& Hudson, I. (2004). Justice, Sustainability and The Fair Trade Movement: A Case Study of Coffee Production in Chiapas. Social Justice. 31(3): 13-146.

Iriye, A. (2007). Globalization as Americanization. Dalam B. Mazlisch, N. Chanda, \& K. Weisbrode, The Paradox of Global USA (hal. 31-48). Stanford: Stanford University Press.

Paul, K., \& Cummins, R. (2014). Five Reasons to Boycott Starbucks. Retrieved from Organic Consumer Association: https://www.organicconsumers.org/essays/five-reasonsboycott-starbucks. Accessed on October 5, 2016.

Renard, M.-C. (2010). In The Name of Conservation: CAFE Practices and Fair Trade in Mexico. Journal of Business Ethics. 92 (Suppl 2): 287-299.

Reynolds, J. (2014). Starbucks sales boosted by Fairtrade espresso shot. Retrieved from Marketing Magazine: http://www.marketingmagazine.co.uk/article/1129138/ starbucks-salesboosted-fairtrade-espresso-shot. Accessed on October 5, 2016

Schor, J. B. (1999). The Overspent American: Why We Want What We Don't Need. William Morrow .

Simon, B. (2009). Everything But The Coffee, Learning About America From Satrbucks. Barkeley: University of California Press.

Skonieczny, A. (2010). Interupting Inevitability; Globalization and Resistance. Alternatives: Global, Local, Political. 35(1): 1-28.

Stanley, A. (2002). Starbucks Coffee Company. Dartmouth: Tuck School of Business Dartmouth College.

Stiglitz, J. (2002). Globalization and Its Discontent. London: Penguin Books.

Singh, M. (2006). India Has Come to Terms with Globalisation. Driving Global Business, (hal. 1-18). Mumbai.

Timmerman, K. (2013, July 21). Follow Your Labels: Starbucks Coffee Farmers Who Never Heard of Starbucks. Retrieved from Christian Science Monitor: http://www. csmonitor.com/World/Global-Issues/2013/0721/Follow-your-labels-Starbuckscoffee-farmers-who-never-heard-of-Starbucks. Accessed on October 10, 2016.

Verhovek, S. H., \& Greenhouse, S. (1999, December 1). National Guard Is Called to Quell Trade-Talk Protests; Seattle Is Under Curfew After Disruptions. Retrieved from New York 
Times: http://www.nytimes.com/1999/12/01/world/national-guard-called-quelltrade-talk-protests-seattle-under-curfew-after.html. Accessed on October 10, 2016.

Welch, D. (2011). Fairtrade beans do not mean a cup of coffee is entirely ethical. Retrieved from The Guardia: http://www.theguardian.com/environment/green-living-blog/2011/feb /28/coffee-chains-ethical. Accessed on October 20, 2016.

World Fair Trade Organization. (2013). 10 Principles of Fair Trade. Diambil kembali dari World Fair Trade Organization: http://www.wfto.com/index.php?option=com _content\&task=view\&id=2\&Itemid=14. Accessed on October 20, 2016. 